\title{
Doctors for a Woman's Choice on Abortion
}

\section{Susan Quilliam}

Writer, Broadcaster, Consultant and Trainer, Cambridge, UK

\section{Correspondence to} Ms Susan Quilliam, Cambridge, UK; susan@susanquilliam.com; http://www.susanquilliam.com

Received 7 April 2014 Accepted 7 April 2014
CrossMark

To cite: Quilliam S. J Fam Plann Reprod Health Care 2014:40:232-233.

\section{WHO ARE YOU?}

Doctors for a Woman's Choice on Abortion is a group of doctors who believe that the law should be changed to allow the woman herself to decide whether or not to have an abortion, and who campaign to defend and improve the current British abortion law.

\section{WHAT ORIGINALLY HAPPENED TO CREATE A NEED FOR THIS ORGANISATION?}

General practitioner Judy Bury started the organisation in 1976 after the White Bill threatened the 1967 Abortion Act. Judy felt that there was a need for an organisation of doctors who were in favour of a woman's choice on abortion in order to counteract the negative press that was current at the time, and to stand against other pro-choice organisations, particularly the organisation Doctors who Respect Human Life.

\section{WHAT ARE YOUR CURRENT AIMS?}

We want to make it clear to the public and Parliament that many doctors feel women themselves should have the right to make the abortion decision, and want to create a change in the law to allow this. We further campaign for improved facilities for abortion, including daycare early medical abortion and the introduction of home medical abortion, as well as campaigning for all areas to meet the standards set down in the Royal College of Obstetricians and Gynaecologists guidelines on The Care of Women Requesting Induced Abortion. ${ }^{1}$ In addition, we aim to answer at a medical level the arguments of anti-abortionists.

\section{WHAT IS YOUR ONGOING WORK?}

We lobby Members of Parliament (MPs) and submit evidence to Parliamentary Committees; for example, during the 2008 attempt to lower the abortion time limit we worked closely with MPs to maintain the limit at 24 weeks. We are on the committee of Voice for Choice, the national coalition of organisations working alongside the All Party Parliamentary Pro-Choice and Sexual Health group.

We also conduct occasional polls to support our campaigning, as well as maintaining a website and blog to inform and support our members.

In the 1980s we used to hold annual scientific meetings, but with the growth of postgraduate education we do not do this anymore. We did hold a meeting to celebrate the 40th anniversary of the 1967 Abortion Act however.

Involved in the day-to-day running of the organisation are Wendy Savage (Co-ordinator and Press Office), Coral Jones (Membership Secretary and Treasurer) and Juliet Stevens (Website Editor).

\section{HOW DO YOU SPREAD THE WORD?}

We neither advertise nor hold public meetings, but we talk to the press when stories emerge about abortion rights for women, or when attacks are made on the status quo. Most recently, abortion counselling and gender-selective abortion have both been in the news, as has a year-long investigation by Education for Choice into the actions of some pregnancy crisis centres.

\section{WHAT HAVE BEEN YOUR BIGGEST TRIUMPHS OVER THE YEARS?}

We managed to get the 1979 Corrie Bill talked out, spending every Monday evening drafting amendments with MPs Ian Mikardo, Jo Richardson (both now deceased) and Oonagh McDonald.

In 1990, we were sitting in the public gallery when the gestational limit was passed as 24 weeks. It was after midnight, and when voting, some of the hard-line anti-abortion MPs went into the wrong lobby and ended up supporting the opposite side! 
WHAT DOES THE FUTURE HOLD?

We are starting a campaign to decriminalise abortion; we are concerned that doctors can have the threat of prosecution hanging over them for 18 months as happened when The Daily Telegraph mounted a sting operation in February 2012.

\section{WHAT IS YOUR BIGGEST CONCERN FOR THE FUTURE?}

As our original members retire or die we need to recruit enough younger members to keep the organisation going for as long as it is needed.

\section{WHAT IS YOUR MESSAGE TO JOURNAL}

\section{READERS?}

It would be good if all Journal readers joined us, particularly lobbying their own MPs and helping in the campaign.
To contact us, visit our website (http://www.dwca. org) from which a joining form can be downloaded.

\section{Competing interests None.}

Provenance and peer review Commissioned; internally peer reviewed.

Editor's note This article is one in a series of occasional articles on key health organisations worldwide. The Journal would be pleased to hear from other organisations, particularly those based outside the UK, which would like to be similarly profiled.

\section{REFERENCE}

1 Royal College of Obstetricians and Gynaecologists. The Care of Women Requesting Induced Abortion. http://www.rcog.org.uk/ womens-health/clinical-guidance/care-women-requestinginduced-abortion [accessed 4 April 2014]. 